\title{
THE ROOT CAUSES AND BASIC INTERESTS FOR ECONOMIC ENTITIES TO ENTER AND MAKING BUSINESS AT THE EXTERNAL MARKETS
}

Purpose. The article is devoted to the study of the root causes of the emergence of interests of economic entities in connection with the beginning of activities at the internal and external markets. Methods. In the research the main scientific methods are widely used. Among them the methods of logical search and synthesis, abstraction and concretization, analogies, modeling are mostly used. Results. The basics of the personal motivation for work and economic activity are discovered. The common hierarchy of needs is applied to the real economic activity of person and entity.

The general reasons, root motives and needs related to economic activity of entrepreneurs are deeply analyzed.

The features of the system of motivation to the economic activity of subjects in the internal and external economic space are determined.

It has been demonstrated that the desire of the subject to engage in entrepreneurial activity both within the country and in the international economic space is similar from the scientific and practical point of view and in fact leads to several common groups of motives.

Conclusions. It is proved that among the prime reasons connected with business interests of the enterprises there are motives for satisfying almost all the standard levels of needs with a clear predominance of the needs of the "highest level", that is, the desire for respect, self-expression and self-realization. It is shown that other needs are always present but play secondary role.

Key words: motivation of economic activity, needs, hierarchy of needs, psychological basis of activity, economic entity's interest, personal economic interest, entrepreneurial activity, work activity.

JEL Classification: D01, D21, D24, D25, D31, D81, D87, D91, F00, F23.

Roman OLEKSIIENKO, Associate professor, Department of Management of the Foreign Economic Activity, University of Customs and Finance, Dnipro (Ukraine),

PhD in Economics,

Associate professor roman.dniepr@gmail.com orcid.org/0000-0003-4029-3840
Introduction. There is no doubt that doing business efficiently requires much more knowledge, skills and efforts than the ordinary work of the hired employee. It can be explained by the relatively high risks and suspense for entrepreneur, because in the case of failure the business owner takes a chance to suffer huge losses and even go bankrupt.

Moreover, when it comes about existence of the entity at external markets where it is advisable to take into account an even much greater variety of factors and conditions of economic activity.

Then what can stimulate, push or compel an economic entity to enter the international market? What are the decisive incentives and motives which have influence on entrepreneur's interests for making business in an economic space that is initially not unusual for him? 
Some issues related to the motivation of work and entrepreneurship were covered by many scientists and researchers such as: Yu. Bogatin, R. Dadahanova, V. Yesaulov, O. Leontiev, V. Nagornov, V. Smirnov, I. Solovenko, V. Schwandar and others. However, the complexity, ambiguity and multidimensionality of aspects connected precisely with the root causes of the subjects' interests as for foreign economic activity stipulates the necessity of further researches in this direction. On this basis, the issues raised in this article concerning the aforementioned area of scientific research are really relevant and useful.

The purpose of this study is to identify and analyze the root causes for economic entities' interests in starting their activities at international markets, to determine the peculiarities of the system of motivation for economic activity of entities in the internal and external economic space.

The basics of needs and motives. It is senseless to disagree with the assumption that any activity or omission of a person is closely related to specific reasons. Such reasons, of course, can be explained by certain physical, psychological, spiritual, material or other moments which depend on the situation, level of development, life position of the person and shape its corresponding behavior. One way or another, if you delve deeper into this issue you can understand that the causes of behavior can be considered as a kind of complex interaction of goals, incentives, interests, motives and needs that force somebody to a certain activity or inaction.

Herewith among the many motivational terms related to incentive forces of behavior the most often researchers identify needs and motives [1]. These two meanings are quite similar for understanding, because they both act as internal regulators of behavior, but there is a significant nuance. Need may be a potential or a real motive for behavior, that is to say it can act or cannot act at a particular moment of time, generating the main state of unintentional activity. In turn, motive is always a relevant, acting factor that precisely transforms human activity into relevant purposeful activity.

According to O. Leontiev, motive performs as a materialized need expressed in a person's desire for the specific goal [2]. Motives are subjective, psychological formations that initiate, regulate and support human activities aimed at satisfying their needs. Needs, in turn, are the objectively active root energetic sources of human behavior, that is, what really drives our decisions and actions.

In that way, exploring the root causes of a subject's interests in a particular activity it is necessary to trace the link between the visible component of the wishes and aspirations of the subject and his real stimulating initial needs.

In this area of research the most convenient to use we can surely consider the hierarchy of needs of A. Maslow, which actually defines the hierarchy of personality motives [3] in the direction from the physiological level to the level of self-realization.

That's undoubtedly and normally to apply these logics to economic agents who deliberately or subconsciously demonstrate by their behavior in the economic environment some effect of one or another root causes on them.

Root causes to enter external markets. It is believed that the main reasons for companies to enter the international markets are, as a rule, their desire to reduce costs and the desire to access unique resources [4].

However, it is obvious that the reasons for economic entity to enter at the international level, first of all, should be connected with the specific goals and interests of the respective enterprise, which are pushing to search for new markets, including international scopes. 
It should be understood that the objectives of an economic entity's entry into the international market can be short-term, operational and long-term [5]. Mostly, they relate to securing or achieving the performance of the enterprise as a whole (in particular, profits, sales, market share) or specific areas of marketing activity in foreign markets. Furthermore, the goals in the external markets are more dynamic than the goals in the national markets which can be explained by the higher level of uncertainty in the behavior of the international economic, political and other environment. Therefore, the environment of international economic activity should be systematically studied and must be taken into account regardless of where the enterprise is located, whether it is already operating on the foreign market or is about to enter the international level of economic activity.

Some researchers propose that the aforementioned goals should be generally perceived as major aspects of motivation that cause national companies to make international business [6] and interpret as:

- expansion of distribution;

- obtaining of resources;

- diversification of sources for supply and distribution, etc.

Indeed, this position can be explained as follows. As you know, total market demand brings together the aggregate demand of individual buyers operating in a particular market. That is to say the more buyers (carriers of demand) exist the more products could be sold. Therefore, sales scope and sales revenue depend directly on the number of buyers available. That's why, in order to increase its own revenues in a situation of limited growth of the number of customers, the entrepreneur should try to expand sales extent of his own products focusing on new markets including international ones.

Apart from that, the international market may create much easier approach for acquiring the resources needed for the enterprise to operate, since such resources may not be available at the domestic market or may be sold much more expensively there. One way or another, the acquisition of relevant resources in the external market can significantly reduce the overall cost of production.

In order to diversify some sources of supply and distribution, the business entity tries to insure itself from possible losses due to certain fluctuations in economic activity both in the national and foreign markets. It is clear that the more diverse sources of supply of relevant resources or opportunities to sell their products can be found, the more reliable activity of a particular enterprise would be. That's because deterioration of the conditions for cooperation with one of the suppliers will not significantly affect the overall situation, countervailing it by the establishing of business relations with other contractors.

Therefore, based on specific goals, the following considerations may serve as the main motives for the economic entity as to enter the international market [7]:

- growth of the company and expansion of its fields of activity;

- the need to maintain and develop the company's image;

- certain trends at the domestic market that push the subject beyond this market (oversaturation of the market with goods; competition strengthening; amplification of taxation level; increasing of dependence upon intermediaries; complexity of legislation compliance);

- seeking to overcome the dependence on the internal market environment with its specific characteristics (for instance, seasonality and hard-to-predict fluctuations), to reduce risks and enable "resource maneuvers"; 
- the desire to access relevant technological secrets;

- the possibility of using national and foreign state programs to promote the development of international trade;

- the desire to release some of the resources used in the internal market (capital, labor, financial resources) to solve more complex and perspective tasks;

- the desire to restore lost or broken business connections, etc.

Grouping of the root causes. The researchers suggest that all the reasons that may be the basis for going abroad from national market could be grouped into four conditional cores [8], depending on certain factors and the level of own initiative that affect the appropriate choice for the subject of economic activity.

Accordingly, the group of active internal causes of the entity's entry into the international market includes those that are the result of the entrepreneur's own initiative. These are reasons that can be conditionally linked to the internal ambitions and desires of the company itself.

The group of active external causes includes those that are opened under certain external circumstances and encourage but do not compel a particular economic entity to act on its own initiative to make an appropriate decision as to enter the international market.

It is advisable to include into the group of reactionary internal causes those that are characterized mostly by the reaction (with a great share of initiative) of the company itself concerning the possibility of certain risks in the future caused by the activity of this entity.

Finally, a group of reactionary external causes may include such objective premises which are independent of the activities and desires of the company itself and which it can only respond on but don't initiate them. These are all reasons for the deterioration of the overall situation and conjuncture at the domestic market.

One way or another, exploring the reasons for the desire of economic subjects to enter foreign markets, it is logical to conclude that there are a great number of such motives, at least not less than the reasons at all as to conduct the relevant economic activities. Moreover, it is obvious that the level of motivation of a subject actually depends on the ultimate success of his entrepreneurial activity.

Affect of risks on the business. Therefore, as we delve into the direction of our research, it is necessary to find out what exactly pushes an ordinary person to start an independent economic activity as a private entrepreneur or to create its own enterprise as a legal entity. It should also be understood that the motivation of the subject to decide to open and run a business should be really significant since it is known that entrepreneurship is always a much riskier business than, for example, the employment of a hired employee.

At the same time the motivation for business activity and the stimulation of work have similar key goals [9]: entrepreneurs and hired employees are interested in earning as much profit or wages as possible while minimizing the costs of resources and labor.

It is interesting to note that the higher the entrepreneur's motivation for success is, the lower his readiness to take risks appears [10]. For example, an indicator such as the risk of production and sales of products is one of the most significant for the entrepreneur. Indeed, high risk is the constant care of the own business, the constant strain in the field of business management, the significant costs of business insurance. However, if the business is not very risky, the motivation to create and run such an entrepreneurial activity can be much greater.

By the way, to predict your own success and more real awareness of the risks in business there is a good advice: all planned revenues should be divided by ten and costs should be multiplied by two [11]. 
So, not every entrepreneur will undertake a risky business unless the motives for its business outweigh the real and potential risks.

Reasoning and thinking concerning real causes. In practice there are many views and hot discussions about the real reasons that may cause the interest to a business start-up and business performing. Moreover, the views are diverse, sometimes quite original and contradictory, but there are typical, generally accepted.

For example, in scientific area the motivation for entrepreneurship is explained from the following points. The decisive reasons for an entrepreneur to enter the market are issues of yield, profitability and goal achievement [12]. At the same time, the material interest expressed in income should be taken as the main stimulating motive of entrepreneurial activity. Profit as an indicator of entrepreneurial performance is considered to be a psychological stimulus and an assessment of the success of the entity. That is why the material motive, even if it is not clearly shown from the outside, still occupies the leading position in the hierarchy of the entrepreneur's goals.

However, it should be kept in mind that the desire to make money can be decisive but not the only motive, since the personality of the entrepreneur as a carrier of a unique resource "entrepreneurial abilities", is distinguished by its diversity of qualities and non-standard thinking.

In particular, researchers agree that achievement of the own goals generates respect for the entrepreneur and significantly increases self-esteem [13]. Entrepreneurial activity allows to reveal its uniqueness and to get independence. Doing things differently than others, influencing the situation, shaping your own world are the strongest incentives that allow entrepreneurs to overcome huge stresses and succeed. Therefore, the highest emotional immersion into the business creates a strong interest of the entrepreneur in the process and results of his own activity. In other words, a strong and, perhaps, the most significant from a moral point of view the motive for entrepreneurial activity can be considered the direct interest in a favorite business, since such commitment to business is gradually becoming not just an activity, but a full life of the entrepreneur.

Ordinary people, in turn, identify the following points among the main motives that encourage entrepreneurial activity [14]. Someone is looking for independence in business, for freedom of the own actions, for opportunity to manage the time and realize the own desires, for realization of a sense of need for personal control of the situation. There are people who explain their impulse to entrepreneurship with certain "desperate situations" in their lives. Others seek selfaffirmation, prove to themselves and others what they are capable of, learn to believe in their own strengths and live up to the expectations of loved ones. A large part perceives entrepreneurship as a pleasure, seeking inspiration, embodying their interests and creative ideas.

From the point of view of entrepreneurs who already have considerable experience and significant achievements, it is advisable to distinguish among others the following reasons that encourage a person to engage in entrepreneurial activity [11]. First, there are challenges - the desire to meet many unexpected moments and interesting tasks that will open up your space for development. Second, it is the desire to become an employer for yourself. Third, it is a sense of responsibility for oneself, for the business and for others. Fourth, it is a constant interest and lack of boredom. Fifth, it is a desire to clearly see and feel the results of your own activities.

One way or another, combining all of the abovementioned information, in theory scientists identify three types of motivation for the real activity [15]: direct, indirect and stimulating.

It is believed that the direct motivation correlates with the degree of interest in the activity and its results. Examples of this type of motivation are the essence and creative component of 
the activity, awareness of the own achievements, their recognition by the environment, a sense of responsibility and self-realization of the personality embodied in this activity. It can be said that activities mostly based on such motivation should bring satisfaction, at least.

At the same time, indirect motivation is clearly related to the degree of material interest. Effective factors in this case may be the form and level of payment for labor, the tension and standards of activity, the rates of change in cost of living, etc.

Finally, the stimulating motivation is formed by a variety of fears and obligations. Such motivation may be due, in particular, to the possibility and rate of unemployment, the uncertainty of tomorrow, the lack of guarantees for work place, the social tension, and more.

Conclusions. Accordingly, as shown by the study, the reasons that explain the subject's desire to engage in entrepreneurial activity both domestically and at the international economic space are similar from scientific and practical points of view. They are connected with several common groups of motives. In turn, the following conclusions can be done from analyzing the aforementioned variants of motivation for activities in terms of the hierarchy of human needs.

Following the desire to find moral pleasure in entrepreneurship, person actually tries to satisfy the own needs of the "highest level", that is, to achieve respect from others (first of all, close people, relatives and acquaintances) and self-esteem, to be convinced in the own abilities, to realize the own life and creative potential.

The desires to be materially independent, free in financial matters, to achieve wealth or so are explained by the tending, first of all, to satisfying the need for the own safety and protection of the loved ones; as well as the desire to recognize the own achievements, which in practice manifests itself in the form of guaranteeing material stability and confidence in tomorrow days, the opportunity to provide a comfortable standard of living with all the necessary benefits. The similar searching for safety and security applies also to the subject's desire to reduce the risks and fears of economic distress and uncertainty about his or her future, that is, to create safer living conditions.

Referring to physiological needs, it can be asserted that the satisfaction of this "lowest level" of human needs should not be attributed to the reasons for the emergence of interest of the subject to engage in business activities and, moreover, to enter external markets, since such basic needs can be satisfied, in particular, even by the ordinary work activity of a hired employee.

In turn, the entrepreneur's attempt to satisfy social needs is, in our opinion, a derivative from the process and result of satisfying the needs of the "highest level", that is to say, the secondary to the abovementioned ones, since the corresponding interest is not paramount in the outlined motivation system of the entrepreneur.

Suchwise, it can be stated that among the root causes of economic subjects' interests in doing business and entering the international markets there are motives for meeting almost all typical levels of needs with a clear overcoming of the needs of the "highest level" such as the desire for respect, self-expression and self-realization.

\section{References:}

1. Obschaya psihologiya: Chto takoye potrebnosti $i$ motivy povedeniya? [The Common Psychology: What are the needs and motives of behavior?] - URL : http://all-psychology.ru/lichnost/ motivy/ponyatie/potrebnost.html (in Russian)

2. Leontiev, A. N. Motivy [Motives]- URL : http://www.psychology-online.net/articles/doc307.html (in Russian)

3. Motivy lichnosti [Motives of individual] - URL : http://psihomed.com/motivyi-lichnosti/ (in Russian) 
4. Prichiny internacionalizacii [Internationalization reasons] - URL : http:// bibliotekar.ru/ biznes-40/93.htm (in Russian)

5. Prichiny vyhoda predpriyatiy na mezhdunarodnyy rynok [Reasons for enterprises to enter the international market] - URL : http://studbooks.net/931245/marketing/prichiny_vyhoda_ predpriyatiy_mezhdunarodnyy_rynok (in Russian)

6. Reshenie o celesoobraznosti vyhoda na vneshnie rynki [The decision on expediency of entering the foreign markets] - URL : http://studbooks.net/1207261/marketing/reshenie tselesoobraznosti_vyhoda_vneshnie_rynki (in Russian)

7. Motivy vyhoda firmy na vneshniy rynok [Motives for enterprise to enter the external market] - URL : http://uchebnik.online/osnovyi-marketinga-besplatno/271-motivyi-vyihoda-firmyivneshniy.html (in Russian)

8. Marketing $i$ rost firm. Pochemu firme stoit idti na zarubezhnye rynki? [Marketing and company growth. Why should a company go to foreign markets?] - URL: http://www.good-reklama. $\mathrm{ru} / \mathrm{rostfirmi} / 55 . h \mathrm{html}$ (in Russian)

9. Nagornov V.I., Esaulov V.N., Solovenko I.S. (2011) Motivaciya predprinimatelskoj deyatelnosti [Motivation of entrepreneurial activity]. Rossijskoe predprinimatelstvo, № 7-1 (187), pp. 140-144. - URL: https://bgscience.ru/viewpdf/?a=2016919 (in Russian)

10. Bogatin Yu.V., Shvandar V.A. Ekonomicheskoe upravlenie biznesom. Motivaciya predprinimatelskoj deyatelnosti [Economic management of the business. Motivation of the entrepreneurial activity] - URL: http://polbu.ru/bogatin_econmanage/ch14_all.html (in Russian)

11. Zachem stanovitsya predprinimatelem? [Why to become an entrepreneur?] - URL : http:// www.dv.ee/novosti/2017/03/28/zachem-stanovitsja-predprinimatelem (in Russian)

12. Dadahanova R.R. (2013) Motivaciya predprinimatelskoj deyatelnosti [Motivation of the entrepreneurial activity]. Molodoj uchenyj, №5, pp. 361-362 (in Russian)

13. Smirnov V.P. Vyyavlenie metodologicheskih osnov predprinimatelskoj deyatelnosti [Identification of methodological foundations of the entrepreneurial activity] - URL : https://cyberleninka.ru/article/n/ vyyavlenie-metodologicheskih-osnov-predprinimatelskoy-deyatelnosti (in Russian)

14. Pochemu lyudi stanovitsya predprinimatelyami? [Why do people become entrepreneurs?] URL : http://www.diforum.ru/topic/9384-почему-люди-становится-предпринимателями/ (in Russian)

15. Ponyatie i tipy motivacii trudovoj deyatelnosti [The concept and types of motivation for work activity] - URL : http://lo1.ru/gos/5/Content/1/1.2.htm (in Russian)

\title{
ПЕРШОПРИЧИНИ ТА БАЗОВІ ІНТЕРЕСИ ЕКОНОМІЧНИХ СУБ'СКТІВ ЩОДО ВИХОДУ ТА ЗДІЙСНЕННЯ БІЗНЕСУ НА ЗОВНІШНІХ РИНКАХ
}

\author{
Роман ОЛЕКСІСНКО, \\ доиент кафедри менеджменту ЗЕД \\ Університету митної справи та фінансів, \\ кандидат економічних наук, доцент, \\ e-mail: roman.dniepr@gmail.com \\ https://orcid.org/0000-0003-4029-3840
}

\begin{abstract}
Мета. Автором даного дослідження за мету поставлено виявити та проаналізувати першопричини виникнення інтересів економічних суб’єктів щзодо початку діяльності на внутрішньому та зовнішньому ринках, а також визначити особливості системи мотиваиії до економічної діяльності суб'єктів у внутрішньому та зовнішньому економічному просторі.

Методи. У ході дослідження активно використовувалися загальнонаукові методи, серед яких найбільшу увагу приділено методам логічного аналізу та синтезу, абстрагування і конкретизації, аналогії, моделювання.

Результати. У межах досягнення поставленої мети розкрито основи особистої мотиваиії до пращі та підприємнищької діяльності. Продемонстровано застосування загальної ієрархї потреб
\end{abstract}


в умовах реальної економічної діяльності окремої людини та суб'єкта економічної діяльності. Глибоко проаналізовані загальні причини, основні мотиви та потреби, пов'язані з різними аспектами економічної діяльності підписмиів.

Визначено особливості системи мотивації до господарської діяльності суб 'єктів у внутрішньому та зовнішньому економічному просторі.

Було продемонстровано, щзо бажання суб'єкта займатися підприємницькою діяльністю як всередині краӥни, так і в міжнародному економічному просторі схоже з наукової та практичноі точки зору і насправді призводить до декількох загальних груп мотивів.

Висновки. Доведено, що серед основних першопричин, пов'язаних із діловими інтересами підприємств, слід сприймати мотиви задоволення майже всіх стандартних рівнів потреб із чітким переважанням потреб «найвищого рівня», тобто прагнення до поваги, власного вираження та самореалізації. При ц̧ьому продемонстровано, щзо й інші потреби завжди присутні, але вони відіграють, здебільшого, другорядну роль.

Ключові слова: мотивація господарської діяльності, потреби, ієрархія потреб, психологічна основа діяльності, інтерес суб'єкта господарювання, особистий економічний інтерес, підприємницька діяльність, трудова діяльність. 